\title{
PENGARUH RELAKSASI AUTOGENIK TERHADAP GULA DARAH PADA PASIEN DM TIPE 2
}

\author{
Wina Rizky Arfi Insani1), Ani Widiastuti2) \\ Fakultas Ilmu Kesehatan \\ Universitas Pembangunan Nasional “Veteran” Jakarta \\ winarizkyai@gmail.com1); ani.andrunaomi@gmail.com²)
}

\begin{abstract}
ABSTRAK
Diabetes melitus tipe 2 merupakan penyakit kronis ditandai hiperglikemia akibat ketidakmampuan melakukan metabolisme karbohidrat, lemak, protein. Diabetes melitus tipe 2 dapat dikontrol dengan terapi nonfarmakologis relaksasi autogenik. Relaksasi Autogenik adalah teknik yang memungkinkan seseorang untuk memperlambat pikiran dan tubuh yang menurunkan detak jantung seseorang, memperlambat system pernapasan, membiarkan darah mengalir lebih mudah melalui tubuh dan meningkatkan fungsi system kekebalan tubuh (Singh, et al, 2018). Tujuan penelitian ini untuk mengetahui pengaruh terapi relaksasi autogenik terhadap kadar gula darah pada pasien diabetes melitus tipe 2 di Puskesmas Pancoran Mas Depok. Penelitian ini menggunakan desain Quasi Experiment dengan rancangan Pretest dan Posttest non equivalent control group. Pengumpulan sampel peneliti menggunakan metode purposive sampling sebanyak 26 responden. Berdasarkan uji parametric T-test pada kelompok intervensi menunjukkan nilai yang signifikan antara pre-post sebesar $0,000(p<0,05)$. Pada kelompok kontrol menunjukkan nilai yang tidak signifikan pada pre-post sebesar $0,570(p>0,05)$. Hasil penelitian ini menunjukkan ada pengaruh terhadap kadar gula darah dan perbedaan yang bermakna sebelum dan sesudah pemberian relaksasi autogenik. Peneliti menyarankan hasil penelitian ini dapat digunakan sebagai bahan masukan bagi dunia keperawatan dan dapat digunakan sebagai pengobatan nonfarmakologi bagi penderita diabetes melitus tipe 2 .
\end{abstract}

Kata Kunci: Relaksasi Autogenik, Kadar Gula Darah, Diabetes Melitus Tipe 2

\begin{abstract}
Type 2 diabetes mellitus is a chronic disease characterized by hyperglycemia due to the inability to carry out metabolism, fat, protein. Type 2 diabetes mellitus can be controlled by autogenic relaxation nonpharmacologic therapy. Autogenic Relaxation is a technique that allows a person to release the mind and body which decreases someone's heart rate, a breathing system, releases blood more easily through the body and improves the functioning of the immune system (Singh, et al, 2018). The purpose of this study was to study autogenic relaxation therapy for blood sugar levels in patients with type 2 diabetes mellitus at Pancoran Mas Public Health Center Depok. This study uses a Quasi Experiment design by designing an unequal pretest and posttest control group. The sample collection of researchers used a purposive sampling method of 26 respondents. Based on parametric test T-test in the intervention group showed a significant value between pre-post of $0,000(p<0.05)$. In the control group showed no significant value at pre-post of 0.570 ( $p>0.05)$. The results of this study indicate there are differences in blood sugar levels and differences suggested before being given autogenic relaxation assistance. Researchers suggest the results of this study can be used as input for the world of nursing and can be used as a nonpharmacological treatment for people with type 2 diabetes mellitus.
\end{abstract}

Keywords: Autogenic Relaxation, Blood Sugar Level, Type 2 Diabetes Mellitus

Alamat: Ani Widiastuti, Keilmuan Keperawatan Medikal Bedah, Fakultas Ilmu Kesehatan, Universitas Pembangunan Nasional “Veteran” Jakarta, Jalan Limo Raya Kelurahan Limo Kota Depok Kode Pos 16515

Email: ani.andrunaomi@gmail.com

Nomor Hp: 081210818495

\section{PENDAHULUAN}

Seiring dengan perkembangan zaman, tingkat kejadian penyakit tidak menular terus meningkat, salah satunya adalah Diabetes Melitus. Diabetes melitus (DM) merupakan penyakit kronis yang umum terjadi pada dewasa yang membutuhkan supervisi medis berkelanjutan dan 
edukasi perawatan mandiri. Diabetes Melitus (DM) adalah penyakit kronis yang ditandai dengan hiperglikemia akibat ketidakmampuan tubuh untuk melakukan metabolisme karbohidrat, lemak, dan protein, kadar gula tinggi menjadi penyebab utama terjadinya komplikasi terkait DM (Black, J.M \& Hawks, J.H, 2014). Diabetes merupakan salah satu dari empat prioritas penyakit tidak menular, dan merupakan penyebab utama untuk kebutaan, serangan jantung, stroke, gagal ginjal, dan amputasi kaki, 80\% penyakit diabetes dapat dicegah (WHO, 2016).

Prevalensi kejadian diabetes melitus terus meningkat sehingga menarik perhatian terutama kalangan praktisi kesehatan. Menurut Organisasi Kesehatan Dunia (WHO), pada tahun 2015 sekitar 415 juta orang hidup dengan diabetes, kenaikan 4 kali lipat dari 108 juta orang di tahun 1980an. Pada tahun 2040 diduga jumlah penderita diabetes melitus akan meningkat menjadi 642 juta (IDF Atlas, 2015). Di Provinsi Jawa Barat sendiri, ada cukup banyak penderita diabetes, terhitung $1,8 \%$ dari total populasi. Provinsi Jawa Barat berada di peringkat 18 untuk kasus Diabetes Melitus di Indonesia (Riskesdas, 2018). Diabetes melitus yang sudah terjadi komplikasi menjadi penyebab mortalitas tertinggi ketiga di Indonesia, 2/3 orang dengan diabetes di Indonesia tidak mengetahui dirinya memiliki diabetes, dan berpotensi untuk mengakses layanan kesehatan dalam kondisi terlambat sudah dengan komplikasi (WHO, 2016).

Penderita rawat jalan di puskesmas menurut golongan umur 45-75 tahun di kota depok tahun 2017, sudah mulai di dominasi oleh penyakit tidak menular, Diabetes Melitus berada pada urutan ke 5 sebesar 7,57\% penderita setelah penyakit Hipertensi Primer sebesar 35,04\% kemudian penyakit ISPA menduduki posisi kedua sebesar $8,72 \%$, penyakit Dispepsia sebesar 7,80\% pada posisi ketiga, dan Myalgia sebesar 7,76\%. Diabetes Melitus masuk ke dalam 10 besar penyakit terbanyak pada pasien rawat jalan puskesmas di kota depok tahun 2017 dengan jumlah sekitar 28.214 penderita (2,98\%) (Lb1 Simpus, 2017 dalam Profil Kesehatan Kota Depok Tahun 2017).

Penatalaksanaan Diabetes Melitus terdapat 4 cara untuk mengontrol kadar gula darah. Cara menjaga kadar gula darah tersebut yaitu; terapi menggunakan obat atau farmakologi, terapi gizi dan nutrisi, edukasi cara manajemen diabetes mandiri, dan aktivitas fisik (American Diabetes Association, 2014). Untuk mencegah terjadinya komplikasi DM, diperlukan pengontrolan terapeutik dan teratur melalui gaya hidup pasien DM tipe 2. Dalam melaksanakan pengontrolan kadar gula darah terdapat beberapa cara diantaranya adalah dengan terapi relaksasi, yang diantaranya terdiri dari PMR, Benson, nafas dalam, relaksasi autogenik (Moyad \& Hawks, 2009 dalam Limbong M, Jaya R, \& Ariani $Y, 2015)$. Teknik relaksasi dengan gerakan instruksi yang lebih sederhana dari pada teknik relaksasi lainnya, hanya memerlukan waktu 15-20 menit, dapat dilakukan dengan posisi berbaring, duduk dikursi dan duduk bersandar yang memungkinkan klien dapat melakukannya dimana saja adalah relaksasi autogenik (Greenberg, 2002 dalam Limbong M, Jaya R, \& Ariani Y, 2015).

Relaksasi Autogenik merupakan bentuk mind body intervention, bersumber dari dalam diri sendiri yang berupa kata-kata atau kalimat pendek yang bisa membuat pikiran menjadi tentram, membuat kata-kata atau kalimat motivasi dilakukan dengan membayangkan diri sendiriberada dalam keadaan tenang dan damai, berfokus pada detak jantung dan pengaturan nafas (Aryani, 2007 dalam Supriadi D, Hutabarat E, \& Putri V, 2015).

Berdasarkan studi pendahuluan yang dilakukan oleh peneliti pada tanggal 2 April 2019, didapatkan data dari Puskesmas Pancoran Mas Depok bahwa setiap bulannya ada sekitar 382 pasien yang rutin kontrol untuk memeriksakan diri ke puskesmas, hasil tersebut didapatkan dari rata-rata jumlah kunjungan pada bulan Januari 403 orang dan bulan Februari 360 orang, dan mendapatkan obat berupa metformin dan glimipirid. Berdasarkan hasil wawancara dari pihak puskesmas diketahui bahwa perawat yang ada di Puskesmas Pancoran Mas sudah non-fungsional, dan berdasarkan hasil wawancara terhadap 5 pasien yang menderita DMT2, mereka rata-rata memiliki nilai gula darah $\geq 200 \mathrm{mg} / \mathrm{dl}$, sering mengalami kaki kesemutan, berkemih dimalam hari, selalu merasa lapar dan haus. Mereka mengatakan saat kontrol ke puskesmas hanya mendapatkan terapi obat-obatan dan mereka juga mengatakan belum mengetahui dan belum pernah melakukan terapi komplementer terapi relaksasi autogenik. Tiga dari lima orang mengatakan bosan dengan penggunaan obat-obatan, namun mereka tetap datang ke puskesmas karena khawatir akan terjadi komplikasi jika tidak diobati. Sisanya dua dari lima orang mengatakan baru selama 2 bulan ini rajin kontrol ke puskesmas. 


\section{METODE PENELITIAN}

Sesuai dengan permasalahan yang telah ditemukan peneliti sebelumnya, maka jenis penelitian yang digunakan dalam penelitian ini adalah Quasi Experiment. Metode penelitian yang dilakukan adalah pre test and post test non equivalent control group yang bertujuan untuk mengetahui pengukuran awal dan pengukuran akhir pada kelompok perlakuan dan kelompok kontrol. Populasi dalam penelitian ini adalah orang yang menderita diabetes melitus tipe 2 di Puskesmas Pancoran Mas Depok. Sampel dalam penelitian ini adalah penderita diabetes melitus tipe 2 yang ada di puskesmas dengan menggunakan perhitungan jurnal sebelumnya oleh Limbong (2015), maka diperoleh jumlah sampel 12,28 dibulatkan menjadi 13, dengan rincian 13 orang kelompok intervensi dan 13 orang kelompok kontrol. Total sampel 26 orang.

Kriteria inklusi dalam penelitian ini adalah: Penderita Diabetes Melitus Tipe 2, Responden dengan kadar glukosa darah sewaktu $\geq 200 \mathrm{mg} / \mathrm{dl}$, Responden yang tidak memiliki gangguan pendengaran, Responden yang tidak pernah dilakukan relaksasi autogenik, Bersedia menjadi responden dan mengisi serta berpartisipasi mengisi kuesioner. Kriteria Eksklusi dalam penelitian ini adalah: Tidak bersedia menjadi responden, Responden yang sudah dilakukan relaksasi autogenic, Responden yang mengkonsumsi obat anti diabetik oral lebih dari 1 jenis obat, Responden yang menggunakan terapi insulin, Responden yang mengalami gangguan pendengaran, Responden yang mengalami gangguan kesadaran. Berdasarkan permasalahan serta fenomena yang diambil oleh peneliti, maka penelitian dilakukan di Puskesmas Pancoran Mas Depok, Waktu Persiapan: Januari 2019 - April 2019, Waktu Pelaksanaan : April 2019 - Juni 2019.

Metode Pengumpulan data dengan menggunakan kuesioner yang dibuat sendiri oleh peneliti yang mengacu pada konsep dan teori yang diuraikan dalam tinjauan pustaka dan hasil penelitian sebelumnya, kuesioner tersebut terdiri atas nama (inisial), umur, jenis kelamin, lama menderita penyakit, dan IMT. alat pengukuran dalam penelitian ini menggunakan glukometer untuk mengukur kadar gula darah dan lembar observasi. Analisis pengaruh relaksasi autogenic terhadap kadar gula darah pada pasien diabetes mellitus tipe 2 di puskesmas pancoran mas depok menggunakan uji $\mathrm{T}$ Independen dan uji T Dependen.

\section{HASIL DAN PEMBAHASAN}

Tabel 1. Distribusi Responden Berdasarkan Rata-rata Usia dan IMT pada Kelompok Intervensi dan Kelompok Kontrol di Puskesmas Pancoran Mas Depok, Tahun 2019 (n=26)

\begin{tabular}{cccccc}
\hline Variabel & Kelompok & Mean & SD & Min & Max \\
\hline Usia & Intervensi & 55,62 & 6,627 & 45 & 65 \\
& Kontrol & 57,08 & 7,444 & 45 & 68 \\
IMT & Intervensi & 26,58 & 4,478 & 16,88 & 35,96 \\
& Kontrol & 25,15 & 4,460 & 16,88 & 34,47 \\
\hline
\end{tabular}

Tabel 1 menunjukkan bahwa diperoleh rata-rata (mean) dari usia responden kelompok intervensi adalah 55,62 dengan standar deviasi 6,627. Usia termuda adalah 45 tahun dan usia tertua responden adalah 65 tahun. Sedangkan rata-rata (mean) dari usia responden kelompok kontrol adalah 57,08 dengan standar deviasi 7,444. Usia termuda responden adalah 45 tahun dan usia tertua responden adalah 68 tahun. Sedangkan dalam variabel IMT, diperoleh rata-rata (mean) dari IMT responden kelompok intervensi adalah 26,58 dengan standar deviasi 4,478. IMT terendah adalah 16,88 dan IMT tertinggi responden adalah 35,96. Sedangkan rata-rata (mean) dari IMT responden kelompok kontrol adalah 25,15 dengan standar deviasi 4,460. IMT terendah responden adalah 16,88 dan IMT tertinggi responden adalah 34,47.

Usia merupakan salah satu faktor risiko DM Tipe 2, dimana semakin bertambahnya usia terjadi intoleransi glukosa yang berlangsung lambat (selama bertahun-tahun) dan progresif, selain itu terjadi resistensi insulin yang cenderung meningkat (Smeltzer \& Bare, 2013). Dengan adanya resistensi insulin (kualitas insulin tidak baik), meskipun insulin ada dan reseptor juga ada, tetapi karena ada kelainan di dalam sel itu sendiri pintu masuk sel tetap tidak dapat mesuk ke sel untuk dimetabolisme. Akibatnya glukosa tetap berada diluar sel, sehingga kadar glukosa dalam darah meningkat 
(Soegondo, 2013) Hasil dari penelitian dan berdasarkan literatur yang didapatkan oleh peneliti, maka peneliti berasumsi bahwa usia yang beresiko mengalami diabetes melitus adalah mulai dari dewasa akhir hingga usia manula, karena semakin bertambahnya usia maka akan terjadi perubahan anatomis, fisiologis, dan biokimia tubuh sehingga terjadi intoleransi glukosa yang berlangsung lambat (selama bertahun-tahun) dan progresif, yang akan memengaruhi kadar gula darah.

Kemenkes RI (2019) untuk memantau status gizi orang dewasa, dihitung dengan indeks massa tubuh (IMT), khususnya yang berkaitan dengan kekurangan dan kelebihan berat badan. Kurus jika IMT < $17 \mathrm{~kg} / \mathrm{m} 2$, normal jika IMT: 17 - $23 \mathrm{~kg} / \mathrm{m} 2$, kegemukan jika IMT: $24-27 \mathrm{~kg} / \mathrm{m} 2$, dan obesitas jika IMT: $>27 \mathrm{~kg} / \mathrm{m} 2$. Hasil penelitian ini menunjukkan bahwa sebagian besar responden pada penelitian ini memiliki rata IMT antara $24-27 \mathrm{~kg} / \mathrm{m} 2$ yang masuk kedalam kategori kegemukan . Berdasarkan penelitian ini, peneliti berasumsi bahwa IMT yang tinggi cenderung memberikan risiko untuk terjadinya diabetes melitus dikarenakan obesitas dapat menghalangi ambilan glukosa ke dalam otot dan sel lemak sehingga glukosa dalam darah meningkat.

Tabel 2. Distribusi Responden Berdasarkan Jenis Kelamin dan Lama Menderita DM pada Kelompok Intervensi dan Kelompok Kontrol di Puskesmas Pancoran Mas Depok, Tahun 2019 (n=26)

\begin{tabular}{ccccc}
\hline Variabel & \multicolumn{2}{c}{ Intervensi } & \multicolumn{2}{c}{ Kontrol } \\
\cline { 2 - 5 } & $\mathbf{( n )}$ & $\mathbf{( \% )}$ & $\mathbf{( n )}$ & $\mathbf{( \% )}$ \\
\hline Jenis Kelamin : & & & & \\
Laki-laki & 4 & 30,8 & 5 & 38,5 \\
Perempuan & 9 & 69,2 & 8 & 61,5 \\
\hline Lama Menderita & & & & \\
5 5 Tahun & 6 & 46,2 & 8 & 61,5 \\
> 5 Tahun & 7 & 53,8 & 5 & 38,5 \\
\hline
\end{tabular}

Tabel 2 dapat diketahui bahwa 4 responden $(30,85)$ berjenis kelamin laki-laki dan 9 responden $(69,2 \%)$ berjenis kelamin perempuan pada kelompok intervensi, serta 5 responden $(38,5 \%)$ berjenis kelamin laki-laki dan 8 responden $(61,5 \%)$ berjenis kelamin perempuan pada kelompok kontrol. Hasil penelitian ini menunjukkan bahwa sebagian besar responden pada penelitian ini adalah perempuan. Sedangkan pada variabel lama menderita DMT2 dapat diketahui bahwa 6 responden (46,2\%) lama menderita diabetes melitus $\leq 5$ tahun dan 7 responden (53,8\%) lama menderita diabetes melitus $>5$ tahun pada kelompok intervensi, serta 8 responden $(61,5 \%)$ lama menderita diabetes melitus $\leq 5$ tahun dan 5 responden $(38,5 \%)$ lama menderita diabetes melitus $>5$ tahun pada kelompok kontrol.

Hasil penelitian ini sejalan dengan penelitian Joseph dkk (2016) hasil penelitian mendapatkan bahwa perempuan lebih banyak menderita DM tipe 2 dibandingkan laki-laki (32,9\%). Perempuan lebih beresiko menderita DM tipe 2 di karenakan perempuan memiliki resiko lebih besar untuk menderita Diabetes Melitus dibandingkan laki-laki, hal ini berhubungan dengan kehamilan dimana kehamilan merupakan faktor resiko untuk terjadinya penyakit diabetes mellitus. Wanita lebih berisiko mengidap DM tipe 2 karena secara fisik wanita memiliki peluang peningkatan indeks masa tubuh yang lebih besar, sindroma siklus bulanan, pasca menopaouse yang membuat distribusi lemak tubuh menjadi mudah terakumulasi akibat proses hormonal. Lama mengalami diabetes, berhubungan secara signifikan dengan kontrol gula darah (HbA1c). Semakin lama individu mengalami diabetes akan meningkatkan kadar HbA1c secara signifikan, menurunkan sensitivitas insulin karena meningkatnya retensi insulin. Kontrol gula darah cenderung lemah pada pasien yang mengalami diabetes lebih dari 6 tahun (Hood et al, 2014). Setiap penambahan 1 tahun durasi diabetes dihubungkan dengan pengurangan 5\% pencapaian target kontrol gula darah (Ahmad et al, 2014). Berdasarkan penelitian ini, peneliti berasumsi bahwa semakin lama individu menderita DM, sensitivitas insulin akan menurun, sehingga kadar gula darah rentan untuk meningkat.

Tabel 3. Distribusi Responden Berdasarkan Rata-rata Kadar Gula Darah pada Kelompok Intervensi dan Kelompok Kontrol di Puskesmas Pancoran Mas Depok, Tahun 2019 $(n=26)$ 


\begin{tabular}{ccccccc}
\hline Kelompok & Variabel & $\mathbf{n}$ & Mean & SD & Min & Max \\
\hline Intervensi & Pretest & 13 & 228,85 & 20,416 & 206 & 263 \\
& Posttest & 13 & 203,69 & 19,133 & 180 & 232 \\
\hline Kontrol & Pretest & 13 & 230,28 & 29,343 & 203 & 286 \\
& Posttest & 13 & 229,71 & 29,649 & 201 & 281 \\
\hline
\end{tabular}

Tabel 3 diatas menunjukkan bahwa kadar gula darah pretest penderita diabetes melitus tipe 2 kelompok intervensi memiliki rata-rata (mean) 228,85 mg/dl dengan SD 20,416 dan kadar gula darah terendah $206 \mathrm{mg} / \mathrm{dl}$ dan tertinggi $263 \mathrm{mg} / \mathrm{dl}$. Sedangkan kelompok kontrol memiliki rata-rata (mean) 230,28 mg/dl dengan SD 29,343 dan kadar gula darah terendah $203 \mathrm{mg} / \mathrm{dl}$ dan tertinggi $286 \mathrm{mg} / \mathrm{dl}$. Sedangkan kadar gula darah posttest penderita diabetes melitus tipe 2 kelompok intervensi memiliki rata-rata (mean) 203,69 mg/dl dengan SD 19,133 dan kadar gula darah terendah $180 \mathrm{mg} / \mathrm{dl}$ dan tertinggi $232 \mathrm{mg} / \mathrm{dl}$. Sedangkan kelompok kontrol memiliki rata-rata (mean) 229,71 mg/dl dengan SD 29,649 dan kadar gula darah terendah $201 \mathrm{mg} / \mathrm{dl}$ dan tertinggi 281mg/dl.

Tabel 4. Analisis Perbedaan Rata-rata Kadar Gula Darah Responden Sebelum dan Sesudah Intervensi Relaksasi Autogenik pada Kelompok Intervensi dan Kontrol di Puskesmas Pancoran Mas Depok, Tahun 2019 (n=26)

\begin{tabular}{cccccccc}
\hline Kelompok & Variabel & $\mathbf{n}$ & Mean & SD & $\begin{array}{c}\text { Mean } \\
\text { Difference }\end{array}$ & SE & $\begin{array}{c}\text { P } \\
\text { Value }\end{array}$ \\
\hline Intervensi & Pretest & 13 & 228,85 & 20,416 & 25,514 & 5,662 & 0,000 \\
& Posttest & 13 & 203,69 & 19,133 & & 5,306 & \\
\hline Kontrol & Pretest & 13 & 230,38 & 29,193 & 0,615 & 8,097 & 0,570 \\
& Posttest & 13 & 229,71 & 29,649 & & 8,223 & \\
\hline
\end{tabular}

Tabel 4 menunjukan bahwa didapatkan uji statistik untuk rata-rata kadar glukosa darah responden terhadap kelompok intervensi untuk pretest dan posttest dengan nilai mean 228,85 mg/dl dan $230 \mathrm{mg} / \mathrm{dl}$, SD 20,416 dan 29,193, untuk nilai $\mathrm{p}$ value 0,000, karena nilai $\mathrm{p}<0,05$ menunjukkan adanya pengaruh yang signifikan antara sebelum dan setelah pemberian intervensi terapi relaksasi autogenic. Untuk kadar gula darah responden terhadap kelompok kontrol pada pretest dan posttest dengan nilai mean 230,38 mg/ dl dan 229,71 mg/dl, SD 29,193 dan 29,649, untuk nilai p value 0,570, karena nilai $\mathrm{p}>0,05$ menunjukkan tidak adanya pengaruh yang signifikan antara sebelum dan setelah pemberian intervensi terapi relaksasi autogenik.

Hasil penelitian ini sejalan dengan Limbong tahun 2015 didapatkan hasil pengambilan data pre dan post kemudian dilakukan uji statistic dengan menggunakan Wilcoxon dan didapatkan hasil $\mathrm{p}=$ 0,001, dengan total responden sebanyak 31 dengan melihat hasil uji statistic maka disimpulkan bahwa pada kelompok intervensi dan kelompok kontrol terdapat perbedaan yang bermakna dengan maing-masing nilai $\mathrm{p}$ value 0,001 .

DiNardo (2009) menuliskan relaksasi autogenic merupakan bentuk mind body therapy, manfaat relaksasi autogenik ini dapat meyakinkan kembali aplikasi konsep lama tentang hubungan pikiran dan respon tubuh, bekerja melalui interaksi respon fisiologis dan psikologis. Relaksasi ini menurunkan hormone kortisol.

Relaksasi ini dimulai dengan latihan napas dalam, latihan ini akan menstimulasi saraf otonom yang mempengaruhi kebutuhan oksigen dengan mengeluarkan neurotransmitter. Respons saraf simpatis dari nafas dalam adalah dengan meningkatkan aktivitas tubuh. Sedangkan respon saraf parasimpatis adalah menurunkan aktivitas tubuh. Penurunan aktivitas tubuh tersebut akan menurunkan konsumsi oksigen. Bila konsumsi oksigen menurun, aktivitas metabolik juga menurun. Akibat penurunan aktivitas metabolik, diharapkan glukosa dalam darah tidak semakin tinggi. Hal tersebut dikarenakan proses nafas dalam akan mengurangi aktivitas otak juga system tubuh lainnya (Potter \& Perry, 2010). 
Stimulus positif dari relaksasi autogenik akan menurunkan aktivitas produksi HPA (Hipotalemik-Pituitary-Adrenal) Axis, yang ditandai adanya penurunan hormon CRF (corticotropinreleasing-factor) di hipotalamus dan juga akan merangsang pituitary anterior untuk memproduksi ACTH menjadi menurun. Penurunan ini akan merangsang medulla adrenal untuk memproduksi hormon katekolamin dan kortisol sebagi homon stres manjadi menurun, sehingga menekan pengeluaran epinefrin dan menghambat konversi glikogen menjadi glukosa, dengan menurunnya kortisol akan menghambat metabolisme glukosa, sehingga asam amino, laktat, dan piruvat tetap disimpan di hati dalam bentuk glikogen dalam bentuk energi cadangan dengan menekan pengeluaran glukagon menghambat mengkonversi glikogen dalam hati menjadi glukosa; dan menekan ACTH dan glukokortikoid pada korteks adrenal sehingga dapat menekan pembentukan glukosa baru oleh hati, selain itu lipolisis dan katabolisme karbohidrat dapat ditekan yang dapat menurunkan kadar gula darah. (Smeltzer, Bare, 2013).

Peneliti berasumsi bahwa adanya pengaruh antara pretest dan post test yang menunjukkan bahwa terapi relaksasi autogenik mampu menurunkan kadar gula darah karena Stimulus positif dari relaksasi autogenik akan menurunkan aktivitas produksi HPA (Hipotalemik-Pituitary-Adrenal) Axis akan merangsang pituitary anterior untuk memproduksi ACTH menjadi menurun. Penurunan ini akan merangsang medulla adrenal untuk memproduksi hormon katekolamin dan kortisol sebagi homon stres manjadi menurun, sehingga menekan pengeluaran epinefrin dan menghambat konversi glikogen menjadi glukosa, dengan menurunnya kortisol akan menghambat metabolisme glukosa.

\section{Tabel 5. Analisis Selisih Kadar Gula Darah Responden Sesudah diberikan Terapi Relaksasi Autogenik pada Kelompok Intervensi dan Kelompok Kontrol di Puskesmas Pancoran Mas Depok, Tahun 2019 (n=26)}

\begin{tabular}{cccccccc}
\hline Variabel & Kelompok & n & Mean & SD & SE & $\begin{array}{c}\text { Mean } \\
\text { Difference }\end{array}$ & $\begin{array}{c}\text { P } \\
\text { Value }\end{array}$ \\
\hline Selisih Kadar & Intervensi & 13 & 25,15 & 3,934 & 1,091 & 24,538 & 0,000 \\
Gula Darah & Kontrol & 13 & 0,62 & 3,798 & 1,053 & 24,538 & \\
\hline
\end{tabular}

Tabel 5 diatas, memperlihatkan bahwa rata-rata selisih kadar gula darah pada kelompok intervensi dapat diturunkan sebesar 25,15 mg/ dl dengan SD 3,934 sedangkan pada kelompok kontrol kadar gula darah turun 0,62 mg/dl dengan SD 3,798. Nilai $\mathrm{p}$ value 0,000, karena nilai $\mathrm{p}<0,05$ menunjukkan bahwa adanya selisih yang signifikan setelah pemberian intervensi terapi relaksasi autogenik pada kelompok intervensi. Sehingga dapat diambil kesimpulan bahwa ada perubahan yang signifikan terapi relaksasi autogenik terhadap kadar gula darah

Penelitian ini sejalan dengan, Junaidin, dkk (2018) adanya selisih kadar gula darah sebelum dan setelah intervensi, sebelum latihan 238,40 setelah latihan mengalami penurunan menjadi 125,68 $\mathrm{mg} / \mathrm{dl}$. Latihan akan membuat tubuh menjadi rileks, system parasimpatis akan merangsang hipotalamus untuk menurunkan sekresi CRH, penurunan CRH akan mempengaruhi sekresi ACTH. Keadaan ini dapat menghambat korteks adrenal untuk melapaskan hormone kortisol. Penurunan kortisol akan menghambat proses gluconeogenesis dan meningkatkan pemakaian glukosa oleh sel, sehingga kadar gula darah kembali dalam batas normal.

Individu yang telah mempraktikan relaksasi secara teratur yaitu sehari sekali selama 15-20 menit akan membuat kondisi kesehatannya berangsur membaik, kondisi emosional lebih seimbang, kualitas tidur meningkat, dan menurunnya level kecemasan. Stress berhubungan erat dengan diabetes, sehingga melalui mekanisme reduksi stress relaksasi autogenik memberikan manfaat bagi intervensi keperawatan, dibuktikan dengan neuroendokrin yang berespon terhadap relaksasi dengan meregulasi hormone kortisol dan hormone stress lainnya, hal ini dikarenakan stress fisik dan emosional mengaktifkan system neuroendokrin dan saraf simpatis melalui hipotalamus-pituitari adrenal (Dinardo, 2009).

Relaksasi ini memiliki pengaruh untuk menurunkan kadar gula darah, relaksasi autogenik ini disebut juga relaksasi psikofisiologi yang telah terbukti melalui beberapa penelitian akan mempengaruhi cara berpikir dan proses tubuh. Relaksasi ini dapat pula dilakukan pada klien rawat 
jalan karena dapat dilakukan sesuai waktu senggang klien. Beberapa penelitian mengungkapkan manfaat relaksasi outogenik ini antara lain menurunkan stres fisiologis, meningkatkan konsentrasi, meningkatkan kualitas tidur, menurunkan depresi dan cemas, meningkatkan penerimaan terhadap perubahan status kesehatan (Bowden, dkk, 2012).

Keuntungan CAM (Complementary and alternative medicine) secara spesifik bagi klien DM juga dikemukakan oleh Riyadi dan Sukarmin (2008) dalam Limbong (2015) yaitu menurunkan kadar glukosa darah. Meningkatkan kontrol metabolik, mencegah neuropati perifer, menurunkan kadar kotekolamin dan aktifitas otonom. CAM memberikan manfaat pada klien DM diantaranya penerimaan terhadap kondisi DM saat ini, menurunkan stres dan depresi, mengembangkan strategi untuk mencegah stres berkelanjutan, meningkatkan keterlibatan klien dalam proses kesembuhan, meningkatkan produksi insulin dan menurunkan resistensi insulin sehingga hipertensi pada DM dapat tertangani, mengurangi mual dan nyeri pada ulkus, menjaga integritas kulit dan meningkatkan pengetahuan bagi klien dan keluarga.

Berdasarkan hasil intepretasi nilai $\mathrm{p}$ value, peneliti menyimpulkan bahwa relaksasi autogenik dapat digunakan untuk pasien diabetes melitus. Terapi ini dapat dilakukan oleh siapa saja karena dalam prosesnya hanya perlu mengetahui teknik sop dan memahami sopnya. Selain itu terapi ini tidak memerlukan biaya yang mahal.

\section{SIMPULAN}

Dari hasil penelitian yang dilakukan terhadap 26 responden yaitu 13 responden kelompok intervensi dan 13 responden kelompok kontrol, dapat dilihat gambaran karakteristik bahwa rata-rata usia responden pada kelompok intervensi yaitu 55 tahun. Gambaran karateristik jenis kelamin paling banyak terdapat pada perempuan 9 responden atau 69,2\%. Gambaran karakteristik lama menderita DMT2 pada kelompok intervensi. terdapat 6 responden $(46,2 \%)$ lama menderita diabetes melitus $\leq 5$ tahun dan 7 responden $(53,8 \%)$ lama menderita diabetes melitus $>5$. Gambaran karakteristik IMT rata-rata (mean) dari IMT responden kelompok intervensi adalah 26,58 dengan standar deviasi 4,478. IMT terendah adalah 16,88 dan IMT tertinggi responden adalah 35,96. Dari hasil penelitian yang dilakukan terhadap 26 responden yaitu 13 responden kelompok intervensi dan 13 responden kelompok kontrol, rata-rata kadar gula darah sebelum diberikan intervensi adalah 228,85 mg/dl sedangkan setelah diberikan intervensi menjadi 203,69 mg/dl

karakteristik responden yang terdiri dari usia, jenis kelamin, lama menderita DMT2, dan IMT didapatkan nilai $p$ value $>0,05$, sehingga dapat disimpulkan bahwa tidak ada pengaruh usia, jenis kelamin, lama menderita DMT2, dan IMT terhadap kadar gula darah pada kelompok intervensi dan kelompok kontrol. Dari hasil analisis pretest dan posttest terdapat adanya pengaruh intervensi relaksasi autogenik terhadap penurunan kadar gula darah pada kelompok intervensi dengan $\mathrm{p}$ value 0,000 sedangkan untuk kelompok kontrol didapatkan $p$ value sebesar 0,570. Rata-rata selisih kadar gula darah pada kelompok intervensi adalah $25,15 \mathrm{mg} / \mathrm{dl}$ dengan SD 3,934, sedangkan pada kelompok kontrol sebesar 0,62 mg/dl dengan SD 3,798.

\section{SARAN}

Bagi Profesi Keperawatan: Sebagai masukan bagi perawat dalam peningkatan atau modifikasi intervensi keperawatan yang tepat pada pasien diabetes mellitus tipe 2., Hasil penelitian ini dapat memberikan masukan bagi profesi keperawatan dalam memberikan terapi nonfarmakologis relaksasi autogenik dalam mengontrol kadar gula darah.

Bagi Institusi Pendidikan: Perlu ditingkatkan lagi mengenai pemberian terapi nonfarmakologis pada penderita diabetes mellitus tipe 2, karena DM sangat berpeluang untuk terjadi komplikasi maka perlu dilaksanakan terapi atau program yang bias dilaksanakan berdampingan dengan terapi farmakologis., Perlu dilakukan penelitian lebih lanjut mengenai efektifitas dari terapi relaksasi autogenik terhadap kadar gula darah.

Bagi Penelitian Selanjutnya: Diharapkan pada peneliti selanjutnya dapat melakukan pemantauan kepatuhan diit diabetes mellitus, Diharapkan pada peneliti selanjutnya dapat melakukan pengontrolan pengelolaan diabetes mellitus yang terdiri dari 4 pilar, Menambah jumlah sampel pada kelompok intervensi dan kelompok kontrol., Memperpanjang durasi waktu penelitian 
supaya mengetahui tren perubahan dari kadar gula darah, Melatih responden terlebih dahulu sampai responden mampu melakukan secara sempurna.

Bagi Masyarakat: Diharapkan sebagai bahan informasi bagi masyarakat khususnya penderita diabetes mellitus tipe 2 sebagai terapi non-farmakologi dan masyarakat dapat membantu menurunkan angka morbiditas maupun mortalitas prevalensi penyakit tidak menular, khususnya diabetes melitus tipe 2 .

\section{DAFTAR PUSTAKA}

Ahmad, dkk. (2014). Factors associated with good glycemic control mong patient with type 2 diabetes mellitus. Journal of diabetic investigation, 5, 563-569

American Diabetes Association. Standards of Medical Care in Diabetes -( 2016). Diabetes Care 2016; 39(Suppl. 1):S13-S22.

American Diabetes Association: Diagnosis and classification of diabetes mellitus. Diabetes Care (2014); 30 (Suppl. 1):S42-S47.

Black, J. M., \& Hawks, J. H. (2014). Keperawatan Medikal Bedah: Manajemen klinis untuk Hasil yang Diharapkan, Edisi 8, Jakarta: Salemba Medika.

DiNardo, M.M. (2009), Mind-body therapies in diabetes management, Diabetes Spectrum, 22 (1). 30.

Depkes RI. (2009), Pedoman Pengendalian Diabetes Melitus dan Penyakit Metabolik. Direktorat Pengendalian Penyakit Tidak Menular, Jakarta

Ekasari, Eya. (2011), Pria lebih rentan terkena diabetes dari pada wanita.

Kementerian Kesehatan Republik Indonesia Kemenkes R.I (2019). IMT, http:/ / www.depkes.go.id/index.php?txtKeyword=status+gizi\&act=search-by-

map\&pgnumber $=0 \&$ charindex $=\&$ strucid $=1280 \&$ fullcontent $=1 \& C-A L L=1$. Diakses Jumat, 26 April 2019

IDF. (2015). Diabetes Fakta dan Angka. International Diabetes Federation, Diunduh dari http://www.idf.org/atlasmap/atlasmap_pada Januari 2019.

Infodatin. (2014). Pusat data dan informasi kementrian kesehatan RI.

Joseph, dkk. (2016). Hubungan Antara Umur, Jenis Kelamin Dan Tingkat Pendidikan Dengan Kejadian Diabetes Melitus Tipe 2 Di Puskesmas Ranotana Weru Kota Manado Tahun 2016. Fakultas Kesehatan Masyarakat Universitas Sam Ratulangi

Kemenkes, Depkes RI. (2018). Riset Kesehatan Dasar (Riskesdas) 2018. Jakarta

Limbong, M (2015). Pengaruh Relaksasi Autogenik Terhadap Kadar Glukosa Darah Pada Pasien Diabetes Melitus Tipe 2. Medan: Universitas Sumatera Utara.

McGill, J.B., Vlajnic, A., Knutsen, P.G., Recklein, C., Rimler, M., Fisher, S. J. (2013). Effect of gender on treatment outcomes in type 2 diabetes melitus. Diabetes Research and Clinical Practice, 02, 167-174

Perry, G. A., \& Potter, A. P (2010). Fundamentals of nursing. Elsevier Mosby

Profil Dinas Kesehatan Kota Depok (2017), Dinas Kesehatan Kota Depok. http://www.depkes.go.id/resources/download/profil/PROFIL_KAB_KOTA_2017/3276_Ja bar_Kota_Depok_2017.pdf. Diakses pada tanggal 26 April 2019

Singh, Amandeep, et al. (2018). Autogenic training and progressive muscle relaxation interventions: Effects On Mental Skills Of Females. European Journal of Physical Education and Sport Science. Doi: 10.5281/zenodo.1598556.

Smeltze C. \& Bare, B.G .(2013). Buku Ajar Keperawatan Medical Bedah Brunner \& Suddarth, volume 2 edisi 8. Jakarta: EGC

Soegondo, S dkk. (2009). Penatalaksanaan diabetes terpadu: sebagai panduan penatalaksanaan diabetes mellitus bagi dokter dan educator. Jakarta: FK UI.

Soegondo, S, dkk. (2013). Penatalaksanaan Diabetes Mellitus Terpadu. Edisi kedua. Jakarta: Badan Penerbit FKUI

Supriadi D, Hutabarat E, \& Putri V. (2015). Pengaruh Terapi Relaksasi Autogenik Terhadap Depresi Pada Lanjut Usia di Balai Perlindungan Sosial Tresna Werdha Ciparay. Bandung: Stikes Jenderal Ahmad Yani. Jurnal kesehatan Vol.10. 